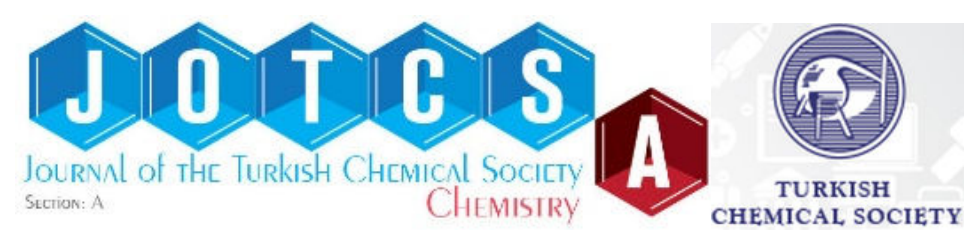

\title{
Novel Antimony(III) Halide Complexes with Some n-Alkyl Thioureas: Synthesis, Characterization and Study of Their Effect upon the Catalytic Oxidation of Linoleic Acid to Hydroperoxylinoleic Acid by Lipoxygenase
}

\author{
Ibrahim Ismet Ozturk* \\ *Department of Chemistry, Namık Kemal University, 59030 Tekirdag, Turkey
}

\begin{abstract}
Four novel thiourea derivatives of antimony(III) compounds ( $\mathrm{SbX} ; ; \mathrm{X}=\mathrm{Cl}$ or $\mathrm{Br}$ ) with $\mathrm{N}$-methylthiourea (NMTU) and N-ethylthiourea (NETU) of formulas [SbCl $(\mathrm{NMTU})_{3}$ ] (1), $\left[\mathrm{SbBr}_{3}(\mathrm{NMTU})_{3}\right](\mathbf{2}),\left[\mathrm{SbCl}_{3}(\mathrm{NETU})_{3}\right]$ (3), and $\left[\mathrm{SbBr}_{3}(\mathrm{NETU})_{3}\right]$ (4) were synthesized. These new antimony(III) halides were characterized by melting point, elemental analysis, molar conductivity, FT-Infrared spectroscopy, FT-Raman spectroscopy, UV-Vis spectrophotometry, NMR $\left({ }^{1} \mathrm{H}\right.$ and $\left.{ }^{13} \mathrm{C}\right)$ spectroscopy and TG-DTA analysis. The reactions of $\mathrm{N}$-methylthiourea (NMTU) and $\mathrm{N}$-ethylthiourea (NETU) with $\mathrm{SbX}_{3}(\mathrm{X}=\mathrm{Cl}$ or $\mathrm{Br})$ in a $2: 1$ ligand/metal rate but unexpected products were formed in a 3:1 ligand/metal rate. The compounds are non-electrolytes in solution and spectroscopic data of the compounds are appropriate with six coordinate octahedral geometry by three halide ions and three sulfur atoms from thiourea ligands. N-methythiourea and $\mathrm{N}$-ethylthiourea ligands behave as monodentate in compounds 1-4 with the binding through sulfur. The influence of these compounds 1-4, N-methythiourea and $\mathrm{N}$-ethylthiourea upon the catalytic peroxidation of linoleic acid to hyperoxolinoleic acid by lipoxygenase was kinetically studied.
\end{abstract}

Keywords: Antimony(III) halides; $\mathrm{N}$-alkyl thioureas; spectroscopic characterization; lipoxygenase.

Submitted: July 23, 2016. Accepted: October 01, 2016.

Cite this: Öztürk İ. Novel Antimony(III) Halide Complexes with Some n-Alkyl Thioureas:

Synthesis, Characterization and Study of Their Effect upon the Catalytic Oxidation of Linoleic Acid to Hydroperoxylinoleic Acid by Lipoxygenase. JOTCSA. 2017;4(1):81-98.

DOI: . 10.18596/jotcsa.31798.

*Corresponding author. E-mail: iiozturk@nku.edu.tr, Tel.:+90 2822502623. 


\section{INTRODUCTION}

Antimony $(\mathrm{Sb})$ is a pnictogenic element and its ground state electron configuration is $5 s^{2} 5 p^{3}$ [1]. Antimony(III) halides, interacting with sulfur donor ligands, behave as Lewis acids, while their compounds show a range of structural motifs. One of the reasons of this geometric diversity of antimony(III) compounds is the lone pair electrons located on the antimony atom [2]. Thus, antimony(III) halide compounds with thioamide ligands contain a five coordinated metal center with a stereochemically active lone pair [3-8]. Antimony has been used as a drug for over more than 100 years. The use of antimony in medicine has been reviewed by Hadjikakou et al. [9]. Antimonials have been used especially for the treatment of leismaniasis (tropical disease) (e.g. melglumineantimoniate (Glucantime) and sodium stibogluconate (Pentostam)) [9]. The potential anticancer activity of antimony compounds is under consideration [9-22]. The last studies indicated that antimony(III) compounds are more active against carcinoma than lymphoma [17]. It is also considerable that antimony(III) compounds demonstrate strong anti-proliferative activity against human cancer cells [17]. Particularly, the antimony(III) compounds demonstrate selectivity against sarcoma and carcinoma cells [17].

Lipoxygenase is a family of iron-containing enzyme which catalyzes the oxidation of arachidonic acid to leukotrienes, in a necessary mechanism for the cell lifetime involving in inflammation mechanism [23-24]. Lipoxygenase inhibition is found to stimulate apoptosis [25], while the lipid peroxides derived from fatty acid metabolism by lipoxygenase can construct cellular proliferation [26]. So, lipoxygenase inhibitions supply a potential new target for the treatment and chemoprevention for a number of diverse cancers.

Thiourea and its derivatives have wide applications in the agricultural area, science of medicine, and analytical chemistry. The chemistry of thioureas has attracted attention owing to their potential use of reagents for the separation of metal ions and as antifungal, antiviral, and antibacterial agents [27-30]. The chemical attention of thiourea derivatives lies in the fact that they are ambidentate ligands with nitrogen and sulfur atoms susceptible for coordination and they have binding sites relevant to those in living organisms [31-32]. The coordination chemistry of thiourea derivatives with p-block elements less well studied than that of the transition metal elements and so this is still a matter of research interest [33-36].

In this work, we report the structural and spectroscopic characterization of four novel antimony (III) halide compounds with the thioureas (Scheme 1), N-methylthiourea (NMTU) and Nethylthiourea (NETU) of formulae $\left[\mathrm{SbCl}_{3}(\mathrm{NMTU})_{3}\right](\mathbf{1}),\left[\mathrm{SbBr}_{3}(\mathrm{NMTU})_{3}\right](\mathbf{2}),\left[\mathrm{SbCl}_{3}(\mathrm{NETU})_{3}\right]$ (3) and $\left[\mathrm{SbBr}_{3}(\mathrm{NETU})_{3}\right](\mathbf{4})$. These new compounds were used to study their influence upon the catalytic peroxidation of linoleic acid by lipoxygenase. 
<smiles>CNC(N)=S</smiles>

N-methythiourea (NMTU)<smiles>CCNC(N)=S</smiles>

N-ethylthiourea (NETU)

Scheme 1. Formulas of the ligands used.

\section{MATERIALS AND METHODS}

\section{Materials and Physical Measurements}

All solvents used were of reagent grade; N-methylthiourea, N-ethylthiourea, and antimony(III) chloride were purchased from Sigma-Aldrich, antimony(III) bromide was purchased from Alfa Aesar. Melting points were measured using a Stuart SMP30 scientific apparatus and are uncorrected. Elemental analyses for $\mathrm{C}, \mathrm{H}, \mathrm{N}$, and $\mathrm{S}$ were carried out with a Carlo Erba EA Model 1108 elemental analyzer. The molecular conductivities of compounds in DMSO were measured by means of a VWR Phenomenal conductometer CO 3000 L. FT-Raman spectra of compounds were obtained at room temperature using a low-power $(\sim 30 \mathrm{~mW})$ green $(514.5) \mathrm{mm}$ laser on a Renishaw In Via spectrometer set at 2.0 resolution. FT-Infrared spectra of compounds from 4000-400 $\mathrm{cm}^{-1}$ were obtained with Bruker Optics, Vertex 70 FT-Infrared spectrometer using ATR technique. The UV spectra of compounds were collected in a Shimadzu UV-2600 spectrophotometer. NMR spectra of compounds were obtained with a Varian Unity Inova 500 MHz spectrometer in DMSO- $\mathrm{d}_{6}$ with chemical shifts given in ppm referenced to internal TMS $(H)$. TG-DTA analysis of compounds were carried out on a Seiko SII TG/DTA 7200 apparatus under $\mathrm{N}_{2}$ flow $\left(50 \mathrm{~cm}^{3} \mathrm{~min}^{-1}\right)$ with a heating rate of $10^{\circ} \mathrm{C} \mathrm{min}^{-1}$.

\section{Synthesis of $\left[\mathrm{SbCl}_{3}(\mathrm{NMTU})_{3}\right](1),\left[\mathrm{SbBr}_{3}(\mathrm{NMTU})_{3}\right](2),\left[\mathrm{SbCl}_{3}(\mathrm{NETU})_{3}\right](3)$ and [SbBr 3 (NETU) $\left.)_{3}\right](4)$}

$1.0 \mathrm{mmol}$ of $\mathrm{N}$-methylthiourea $(0.090 \mathrm{~g})$ in benzene $(10 \mathrm{~mL})$ was added to a benzene $(10 \mathrm{~mL})$ solution of $\mathrm{SbCl}_{3}(0.5 \mathrm{mmol}, 0.114 \mathrm{~g})$ for compound 1 and to $\mathrm{SbBr}_{3}(0.5 \mathrm{mmol}, 0.181 \mathrm{~g})$ for compound 2. $1.0 \mathrm{mmol} \mathrm{N}$-ethylthiourea $(0.104 \mathrm{~g})$ in benzene $(10 \mathrm{~mL})$ was added to a benzene $(10 \mathrm{~mL})$ solution of $\mathrm{SbCl}_{3}(0.5 \mathrm{mmol}, 0.114 \mathrm{~g})$ for compound 3 and to $\mathrm{SbBr}_{3}(0,5 \mathrm{mmol}, 0,181$ g) for compound $\mathbf{4}$ and then the solutions were stirred for $30 \mathrm{~min}$, then they were filtered off and then the resulting clear solutions were kept in darkness at room temperature to give compounds of the antimony(III) halide. All compounds are soluble in acetone, acetonitrile, dimethyl sulfoxide, ethanol, methanol, and tetrahydrofuran.

Result for 1: Yellow crystals; yield $89 \%$; mp, $114-118^{\circ} \mathrm{C}$; mw, $498.56 \mathrm{~g} / \mathrm{mol}$; Found for $\mathrm{C}_{6} \mathrm{H}_{18} \mathrm{Cl}_{3} \mathrm{~N}_{6} \mathrm{~S} 3 \mathrm{Sb}: \mathrm{C}: 14.38 ; \mathrm{H}: 3.51 ; \mathrm{N}: 16.75 ; \mathrm{S}: 19.15$, Calc. for C: $14.45 ; \mathrm{H}: 3.64 ; \mathrm{N}: 16.89$; S: 19.29. UV-Vis (DMSO): $\lambda_{\max }(\log \varepsilon)=257.50(4.55)$. FT-IR $\left(\mathrm{cm}^{-1}\right): 3244 \mathrm{~m}, 3161 \mathrm{~s}, 1626 \mathrm{~s}$, 
$1551 \mathrm{~s}, 1489 \mathrm{~m}, 1452 \mathrm{~m}, 1402 \mathrm{~m}, 1338 \mathrm{w}, 1292 \mathrm{~s}, 1255 \mathrm{w}, 1146 \mathrm{w}, 1122 \mathrm{~s}, 972 \mathrm{~s}, 773 \mathrm{~s}, 715 \mathrm{~s}, 633 \mathrm{~m}$, $598 \mathrm{w}, 544 \mathrm{~m}, 482 \mathrm{~s} . \Lambda_{M}=8.8 \Omega^{-1} \cdot \mathrm{cm}^{2} \cdot \mathrm{mol}^{-1}$.

Result for 2: Yellow crystals; yield $85 \%$; mp, $86-89^{\circ} \mathrm{C}$; $\mathrm{mw}, 631.91 \mathrm{~g} / \mathrm{mol}$; found for $\mathrm{C}_{6} \mathrm{H}_{18} \mathrm{Br}_{3} \mathrm{~N}_{6} \mathrm{~S}_{3} \mathrm{Sb}: \mathrm{C}: 11.38 ; \mathrm{H}: 2.91 ; \mathrm{N}: 13.24 ; \mathrm{S}: 15.12$, Calc. for C: $11.40 ; \mathrm{H}: 2.87 ; \mathrm{N}: 13.30$; S: 15.22. UV-Vis (DMSO): $\lambda_{\max }(\log \varepsilon)=258.00$ (4.63). FT-IR $\left(\mathrm{cm}^{-1}\right): 3246 \mathrm{~m}, 3161 \mathrm{~s}, 1624 \mathrm{~s}$, $1553 \mathrm{~s}, 1487 \mathrm{~m}, 1452 \mathrm{~m}, 1402 \mathrm{~m}, 1338 \mathrm{w}, 1290 \mathrm{~s}, 1257 \mathrm{w}, 1147 \mathrm{w}, 1122 \mathrm{~s}, 972 \mathrm{~s}, 771 \mathrm{~s}, 715 \mathrm{~s}, 632 \mathrm{~s}$, $600 \mathrm{w}, 542 \mathrm{~m}, 476 \mathrm{~s} . \Lambda_{\mathrm{M}}=23.1 \Omega^{-1} \cdot \mathrm{cm}^{2} \cdot \mathrm{mol}^{-1}$.

Result for 3: Light yellow crystals; yield $87 \%$; $\mathrm{mp}, 63-65^{\circ} \mathrm{C} ; \mathrm{mw}, 540.64 \mathrm{~g} / \mathrm{mol}$; found for $\mathrm{C}_{9} \mathrm{H}_{24} \mathrm{Cl}_{3} \mathrm{~N}_{6} \mathrm{~S} 3 \mathrm{Sb}: \mathrm{C}: 19.84 ; \mathrm{H}: 4.42 ; \mathrm{N}: 15.34 ; \mathrm{S}: 17.45$,Calc. for C: $19.99 ; \mathrm{H}: 4.47 ; \mathrm{N}: 15.54$; S: 17.79. UV-Vis (DMSO): $\lambda_{\max }(\log \varepsilon)=257.50$ (4.49). FT-IR $\left(\mathrm{cm}^{-1}\right): 3323 \mathrm{w}, 3277 \mathrm{w}, 3230 \mathrm{w}$, $3147 \mathrm{~s}, 2974 \mathrm{~m}, 1618 \mathrm{~s}, 1556 \mathrm{w}, 1541 \mathrm{~s}, 1500 \mathrm{w}, 1466 \mathrm{~m}, 1379 \mathrm{~m}, 1344 \mathrm{~m}, 1304 \mathrm{w}, 1261 \mathrm{~s}, 1080 \mathrm{w}$, $1032 w, 1009 w, 903 w, 891 w, 821 w, 802 s, 739 s, 644 s, 542 w, 486 s, 444 w, 424 w . \Lambda_{m}=13.9 \Omega^{-}$ ${ }^{1} \cdot \mathrm{cm}^{2} \cdot \mathrm{mol}^{-1}$.

Result for 4: Light yellow crystals; yield $89 \%$; $\mathrm{mp}, 68-71^{\circ} \mathrm{C}$; $\mathrm{mw}, 673.99 \mathrm{~g} / \mathrm{mol}$; found for $\mathrm{C}_{9} \mathrm{H}_{24} \mathrm{Br}_{3} \mathrm{~N}_{6} \mathrm{~S}_{3} \mathrm{Sb}$ : C: $15.98 ; \mathrm{H}: 3.52 ; \mathrm{N}: 12.35 ; \mathrm{S}: 14.19$,Calc. for C: $16.04 ; \mathrm{H}: 3.59 ; \mathrm{N}: 12.47$; S: 14.27 . UV-Vis (DMSO): $\lambda_{\max }(\log \varepsilon)=258.50$ (4.73). IR $\left(\mathrm{cm}^{-1}\right): 3323 \mathrm{w}, 3277 \mathrm{w}, 3232 \mathrm{w}, 3147 \mathrm{~s}$, $2974 \mathrm{~m}, 1618 \mathrm{~s}, 1541 \mathrm{~s}, 1498 \mathrm{w}, 1446 \mathrm{w}, 1379 \mathrm{~m}, 1344 \mathrm{~m}, 1304 \mathrm{w}, 1263 \mathrm{~s}, 1171 \mathrm{w}, 1126 \mathrm{~s}, 1113 \mathrm{w}$, $1080 w, 1032 w, 1009 w, 902 w, 891 w, 822 w, 802 s, 739 s, 644 s, 544 w, 488 s, 445 w, 426 w . \Lambda_{M}=$ $23.5 \Omega^{-1} \cdot \mathrm{cm}^{2} \cdot \mathrm{mol}^{-1}$.

\section{Study of lipoxygenase inhibition mechanism}

Preparation of the solutions: $0.2 \mathrm{M}$ borate buffer solution was used in all kinetic studies. Borate buffer solution was prepared as defined here: $6.18 \mathrm{~g}$ boric acid $\left(\mathrm{H}_{3} \mathrm{BO}_{3}, 0.1 \mathrm{~mol}\right)$ was added to $300 \mathrm{~mL}$ distilled water. The $\mathrm{pH}$ was calibrated to 9 with $50 \% \mathrm{w} / \mathrm{v}$ sodium hydroxide. Lastly, the solution was diluted to $500 \mathrm{~mL}$ with distilled water [37]. Linoleic acid solution was prepared as defined here: $0.05 \mathrm{~mL}$ of linoleic acid was dissolved in $0.05 \mathrm{~mL}$ of ethanol (95\%). $50 \mathrm{~mL}$ of $\mathrm{H}_{2} \mathrm{O}$ was added in the flask. $5 \mathrm{~mL}$ of the prepared solution was added to $30 \mathrm{~mL}$ of the buffer solution. Enzyme solution: $10000 \mathrm{U}$ of enzyme solution for each $\mathrm{mL}$ of buffer solution was prepared in ice-cold bath [38]. An amount of $500 \mathrm{U}$ for every $3 \mathrm{~mL}$ of reaction mixture is used in every experiment. A unit of lipoxygenase causes and increases in absorption at $234 \mathrm{~nm}$ equal to 0.001 per minute.

\section{Method}

The activity of enzyme was observed by UV spectroscopy. The enzyme solution $(0.05 \mathrm{~mL})$ was added to a cell containing $2 \mathrm{~mL}$ of linoleic acid solution and a necessary amount of the buffer solution. The temperature of a solution of the inhibitor was preserved constant at $25^{\circ} \mathrm{C}$. No preincubation of the enzyme with an inhibitor solution was applied. The enzyme activity was established from an increase in the absorption intensity at $234 \mathrm{~nm}$ at $25^{\circ} \mathrm{C}\left(\varepsilon=25000 \mathrm{~L} \mathrm{~mol}^{-}\right.$ 
${ }^{1} \mathrm{~cm}^{-1}$ ) [39-41] caused by the oxidation of linoleic acid. Solutions of antimony(III) halide compounds 1-4 were prepared in dimethyl sulfoxide, concentrations of compounds being $10^{-1}$ and $10^{-2} \mathrm{~mol} . \mathrm{L}^{-1}$. The substrate concentration was preserved constant at a level of $0.3 \mathrm{mmol} . \mathrm{L}^{-}$ 1 , and the amounts of buffer and inhibitor solutions were altered according to the necessary final concentration of the inhibitor. The whole volume of the reaction mixture was $2 \mathrm{~mL}$. Every experiment was repeated three times. All solutions were kept at thermostatic water bath at $25^{\circ} \mathrm{C}$, except from the enzyme solution that was kept at ice cold bath $\left(0^{\circ} \mathrm{C}\right)$.

\section{RESULTS AND DISCUSSION}

\section{General Aspects}

Antimony(III) halide compounds 1-4 were synthesized in benzene solution by reacting the thioureas with antimony(III) halide, as shown in Eq. 1. All the reactions were built in 2:1 ligand to metal rate. $\mathrm{N}$-methythiourea and $\mathrm{N}$-ethythiourea are coordinated to antimony through their neutral forms while no deprotonation occurred. Compounds 1-4 were characterized by melting point, elemental analysis, molar conductivity, FT-Infrared spectroscopy, FT-Raman spectroscopy, TG-DTA analysis, UV-Vis spectrophotometry and NMR spectroscopy. All compounds are air-stable. The melting points and elemental analyses of the compounds are given in Table 1. All compounds are neutral with octahedral $\left(\mathrm{O}_{h}\right)$ geometry with $3: 1 \mathrm{HL} / \mathrm{SbX}_{3}$ ratio (Figure 1 ).

$$
\begin{aligned}
& \mathbf{S b X}_{\mathbf{3}}+\mathbf{2} \mathbf{H L} \underset{\text { Benzene }}{\longrightarrow}\left[\mathbf{S b X}_{\mathbf{3}}(\mathbf{H L})_{\mathbf{3}}\right] \\
& \mathbf{X : C l} \text { or } \mathrm{Br} \\
& \mathbf{H L}: \mathrm{N} \text {-methythiourea (NMTU), N-ethylthiourea (NETU) }
\end{aligned}
$$

\begin{tabular}{|c|c|c|c|c|c|c|}
\hline \multirow{2}{*}{ Compounds } & \multirow{2}{*}{$\begin{array}{l}\text { Yield } \\
(\%)\end{array}$} & \multirow{2}{*}{$\mathrm{mp}\left({ }^{\circ} \mathrm{C}\right)$} & \multicolumn{4}{|c|}{ Found (Calculated) (\%) } \\
\hline & & & C & H & $\mathbf{N}$ & $\mathbf{S}$ \\
\hline $\begin{array}{c}{\left[\mathrm{SbCl}_{3}\left(\mathrm{NMTU}_{3}\right)_{3}\right]} \\
\text { (1) }\end{array}$ & 89 & $\begin{array}{c}114-118 \\
{ }^{\circ} \mathrm{C}\end{array}$ & $\begin{array}{c}14.38 \\
(14.45)\end{array}$ & $\begin{array}{c}3.51 \\
(3.64)\end{array}$ & $\begin{array}{c}16.75 \\
(16.89)\end{array}$ & $\begin{array}{c}19.15 \\
(19.29)\end{array}$ \\
\hline $\begin{array}{c}{\left[\mathrm{SbBr}_{3}(\mathrm{NMTU})_{3}\right]} \\
(2)\end{array}$ & 85 & $86-89^{\circ} \mathrm{C}$ & $\begin{array}{c}11.38 \\
(11.40)\end{array}$ & $\begin{array}{c}2.91 \\
(2.87)\end{array}$ & $\begin{array}{c}13.24 \\
(13.30)\end{array}$ & $\begin{array}{c}15.12 \\
(15.22)\end{array}$ \\
\hline$\left[\mathrm{SbCl}_{3}(\mathrm{NETU})_{3}\right]$ (3) & 87 & $63-65^{\circ} \mathrm{C}$ & $\begin{array}{c}19.84 \\
(19.99)\end{array}$ & $\begin{array}{c}4.42 \\
(4.47)\end{array}$ & $\begin{array}{c}15.34 \\
(15.54)\end{array}$ & $\begin{array}{c}17.45 \\
(17.79)\end{array}$ \\
\hline $\begin{array}{c}{\left[\mathrm{SbBr}_{3}(\mathrm{NETU})_{3}\right]} \\
(4)\end{array}$ & 89 & $68-71^{\circ} \mathrm{C}$ & $\begin{array}{c}15.98 \\
(16.04)\end{array}$ & $\begin{array}{c}3.52 \\
(3.59)\end{array}$ & $\begin{array}{c}12.35 \\
(12.47)\end{array}$ & $\begin{array}{c}14.19 \\
(14.27)\end{array}$ \\
\hline
\end{tabular}

Table 1. Yields, melting points and elemental analysis of antimony(III) halide compounds. 

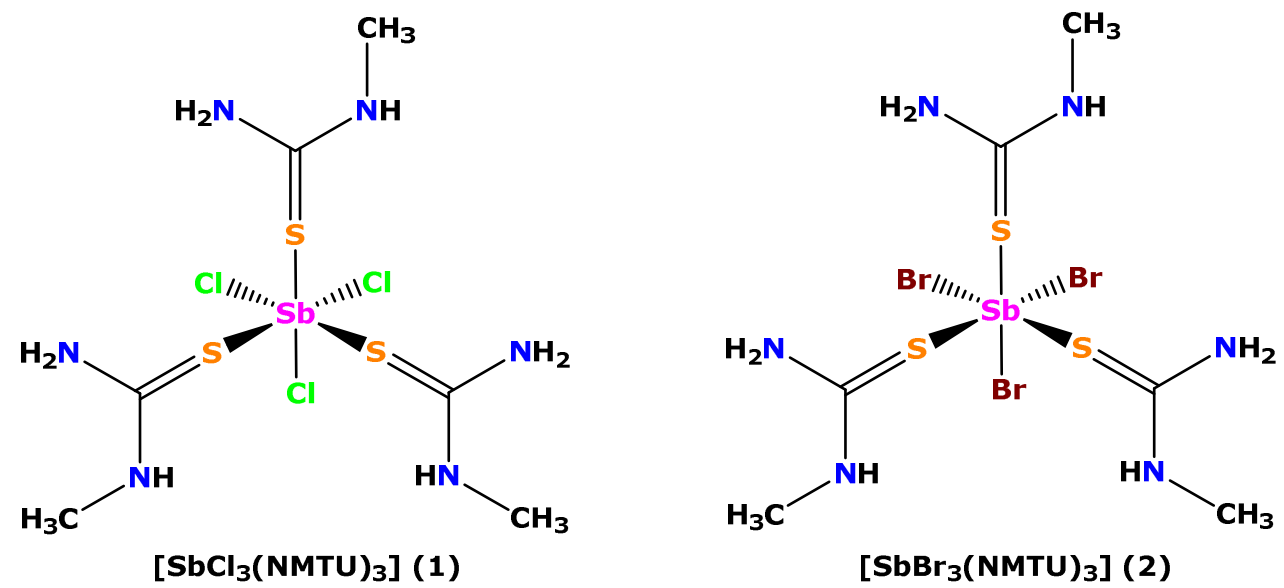

$\left[\mathrm{SbBr}_{3}(\mathrm{NMTU})_{3}\right](2)$

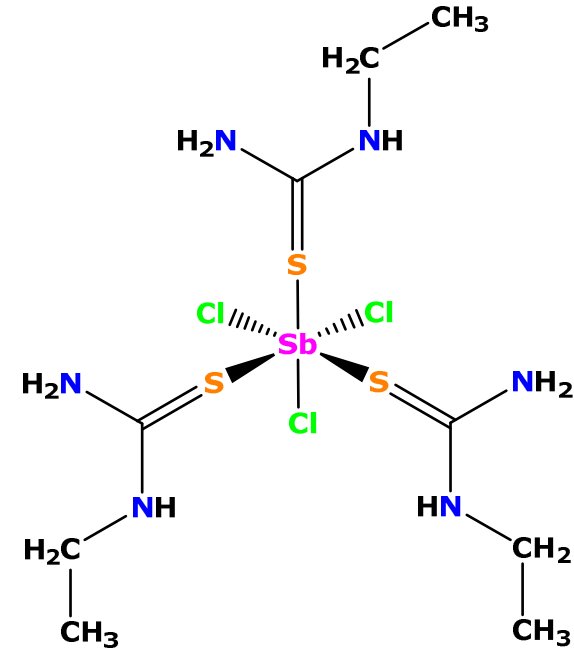

$\left[\mathrm{SbCl}_{3}(\mathrm{NETU})_{3}\right](3)$<smiles>CCNC(N)=[SH][Sb](Br)(Br)(Br)(SCC)SC(N)=S(N)NCC</smiles>

$\left[\mathrm{SbBr}_{3}(\mathrm{NETU})_{3}\right](4)$

Figure 1. Proposed structures for antimony(III) halide compounds of N-methythiourea and Nethylthiourea.

\section{Molar Conductivity Studies}

The molar conductance values of $10^{-3} \mathrm{M}$ antimony(III) compounds 1-4 were obtained in dimethyl sulfoxide at room temperature. The measured molar conductance values of antimony(III) compounds are $8.8 \Omega^{-1} \cdot \mathrm{cm}^{2} \cdot \mathrm{mol}^{-1}(\mathbf{1}), 23.1 \Omega^{-1} \cdot \mathrm{cm}^{2} \cdot \mathrm{mol}^{-1}(\mathbf{2}), 13.9 \Omega^{-1} \cdot \mathrm{cm}^{2} \cdot \mathrm{mol}^{-1}(3)$ and $23.5 \Omega^{-}$ ${ }^{1} . \mathrm{cm}^{2} \cdot \mathrm{mol}^{-1}(4)$ respectively. Generally higher molar conductance values are determinative of the electrolytic nature of the metal compounds and lower values display their non-electrolytic nature [42]. The molar conductance values of antimony(III) compounds indicating that compounds 1-4 are non-electrolytes.

\section{FT-Infrared and FT-Raman Spectral Studies}

Characteristic infrared bands of the antimony(III) halide compounds and the free thioureas are shown in Table 2 and Figure 2. The characteristic infrared bands, responsive to molecular structure, are the strain modes for the $\mathrm{v}(\mathrm{N}-\mathrm{H}), \mathrm{v}(\mathrm{C}=\mathrm{S})$ and $\mathrm{v}(\mathrm{C}-\mathrm{N})$ bands $[8,15-16]$. The infrared spectra of compounds represent distinct vibration bands at $1551 \mathrm{~cm}^{-1}(\mathbf{1}), 1553 \mathrm{~cm}^{-1}(\mathbf{2}), 1541$ 
$\mathrm{cm}^{-1}(3)$ and $1541 \mathrm{~cm}^{-1}(4)$, respectively, which are attributed to the $\mathrm{v}(\mathrm{C}-\mathrm{N})$ vibrations. Bands at $773 \mathrm{~cm}^{-1}(\mathbf{1}), 771 \mathrm{~cm}^{-1}(\mathbf{2}), 802 \mathrm{~cm}^{-1}(\mathbf{3})$, and $802 \mathrm{~cm}^{-1}(4)$ are attributed to the $\mathrm{v}(\mathrm{C}=\mathrm{S})$ vibrations. Amide $\mathrm{v}(\mathrm{N}-\mathrm{H})$ vibrations were monitored in the region of $3323-3147 \mathrm{~cm}^{-1}$ in compounds 1-4. The corresponding vibrations at the free thioureas are found at $3327-3165 \mathrm{~cm}^{-}$ $1,1543 \mathrm{~cm}^{-1}$ and $775 \mathrm{~cm}^{-1}$ (NMTU), $3327-3147 \mathrm{~cm}^{-1}, 1541 \mathrm{~cm}^{-1}$ and $804 \mathrm{~cm}^{-1}$ (NETU). A low frequency shifts in the $v(C=S)$ band and high frequency shifts in $v(C-N)$ band indicate that coordination happens through sulfur atoms of the thioureas in the solid state. Since no $v(S-H)$ vibrations are observed in the infrared spectrum of 1-4 indicating that the free ligands are coordinated through their thione forms. Sb-S and $\mathrm{Sb}-\mathrm{X}(\mathrm{X}: \mathrm{Cl}$ or $\mathrm{Br}$ ) vibrations are Raman-active $[8,15-16]$. Thus, bands at $412 / 406 \mathrm{~cm}^{-1}(\mathbf{1}), 443 \mathrm{~cm}^{-1}(2), 408 \mathrm{~cm}^{-1}(3)$ and $444 \mathrm{~cm}^{-1}(4)$ in the Raman spectra of compounds 1-4 are owing to the Sb-S vibrations. Bands at $191 / 136 \mathrm{~cm}^{-1}$ in $\mathbf{1}$ and $199 / 191 / 133 \mathrm{~cm}^{-1}$ in $\mathbf{3}$ are attributed to the $\mathrm{Sb}-\mathrm{Cl}$ vibrations, while band at $108 / 100 \mathrm{~cm}^{-1}$ in 2 and $105 \mathrm{~cm}^{-1}$ in $\mathbf{4}$ has been assigned to the Sb-Br vibrations (Figures S1-S4).

Table 2. Selected IR and Raman spectroscopic data for compounds 1-4 and free ligands.

\begin{tabular}{|c|c|c|c|c|c|}
\hline \multirow[b]{2}{*}{ Compound } & \multicolumn{3}{|c|}{ Mid-IR $\left(\mathrm{cm}^{-1}\right)$} & \multicolumn{2}{|c|}{$\operatorname{Raman}\left(\mathrm{cm}^{-1}\right)$} \\
\hline & $\mathbf{v}(\mathrm{N}-\mathrm{H})$ & $\mathbf{v}(\mathrm{C}-\mathrm{N})$ & $\mathbf{v}(\mathrm{C}=\mathrm{S})$ & $\mathbf{v}(\mathbf{S b}-\mathbf{S})$ & $\mathbf{v}(\mathbf{S b}-\mathbf{X})$ \\
\hline NMTU & $3327,3246,3165$ & 1543 & 775 & - & - \\
\hline$\left[\mathrm{SbCl}_{3}(\mathrm{NMTU})_{3}\right](1)$ & 3244,3161 & 1551 & 773 & 412,406 & 191,136 \\
\hline$\left[\mathrm{SbBr}_{3}(\mathrm{NMTU})_{3}\right](2)$ & 3246,3161 & 1553 & 771 & 443 & 108,100 \\
\hline NETU & $3327,3232,3147$ & 1541 & 804 & - & \\
\hline$\left[\mathrm{SbCl}_{3}(\mathrm{NETU})_{3}\right](3)$ & $3323,3230,3147$ & 1541 & 802 & 408 & $199,191,133$ \\
\hline$\left[\mathrm{SbBr}_{3}(\mathrm{NETU})_{3}\right](4)$ & $3323,3232,3147$ & 1541 & 802 & 444 & 105 \\
\hline
\end{tabular}




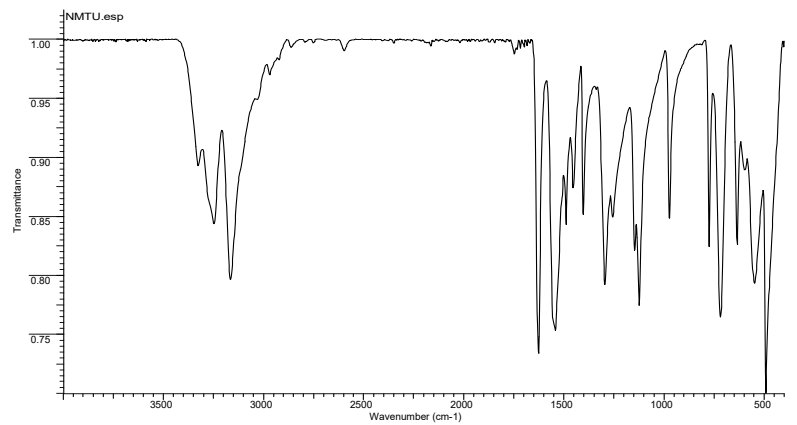

(A)

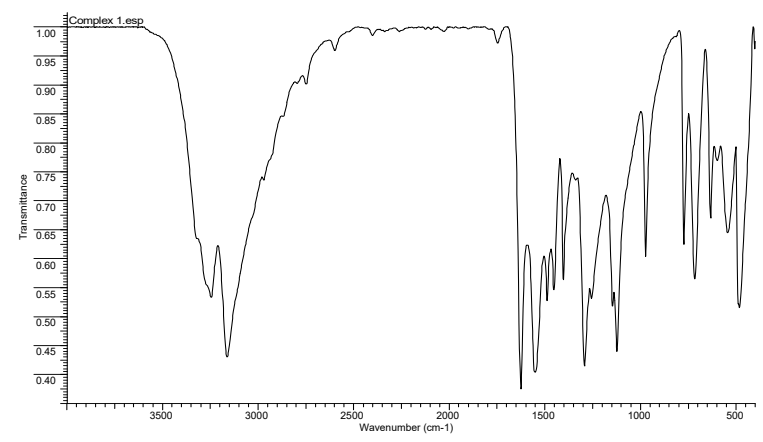

(C)

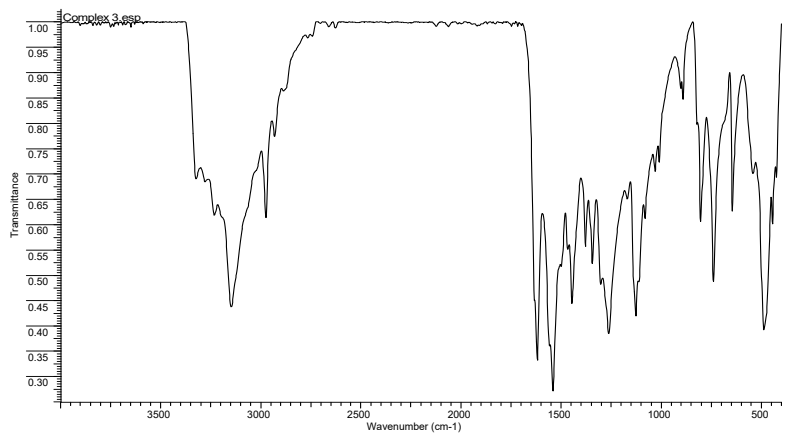

(E)

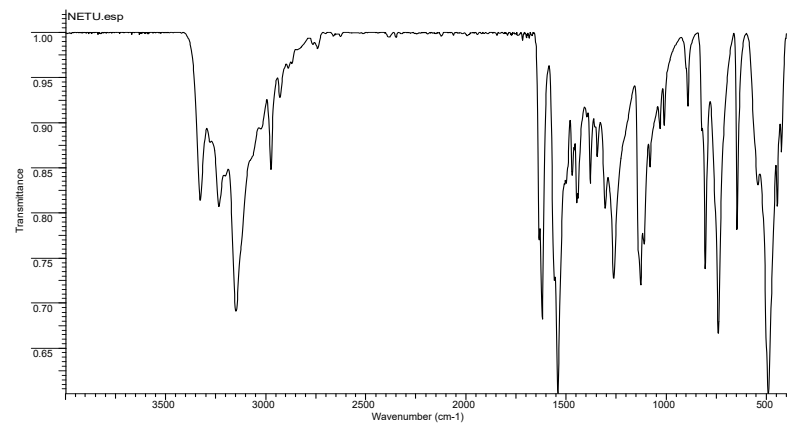

(B)

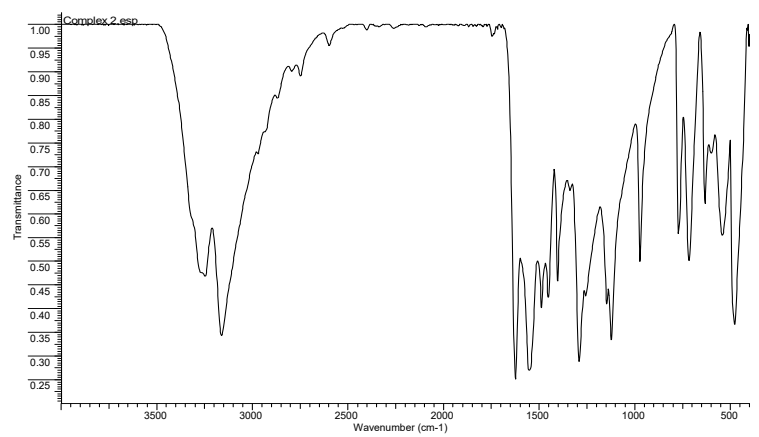

(D)

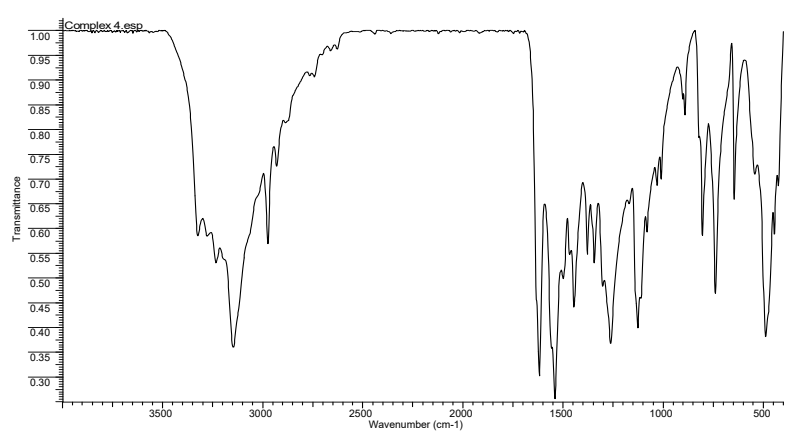

(F)

Figure 2. Infrared spectra of: (A) N-methylthourea, (B) N-ethylthiourea, (C) $\left[\mathrm{SbCl}_{3}(\mathrm{NMTU})_{3}\right]$ (1), (D) $\left[\mathrm{SbBr}_{3}(\mathrm{NMTU})_{3}\right](\mathbf{2}),(\mathbf{E})\left[\mathrm{SbCl}_{3}(\mathrm{NETU})_{3}\right](\mathbf{3})$ and (F) $\left[\mathrm{SbBr}_{3}(\mathrm{NETU})_{3}\right]$ (4)

\section{Thermal Analysis}

The thermal stability of antimony(III) halide compounds 1-4 is tested by TG-DTA analysis in an atmosphere of nitrogen in the range $25-800{ }^{\circ} \mathrm{C}$. The data show that compounds $\mathbf{1 - 4}$ remain stable up to $149^{\circ} \mathrm{C}(\mathbf{1}), 138^{\circ} \mathrm{C}(\mathbf{2}), 146^{\circ} \mathrm{C}(\mathbf{3})$, and $160^{\circ} \mathrm{C}(\mathbf{4})$, respectively (Figure 2). Beyond these temperatures, compounds 1, 2 and $\mathbf{4}$ have one decomposition step, while $\mathbf{3}$ has two decomposition steps.

\section{UV-Vis Spectral Studies}

The UV-Vis spectra of the free $\mathrm{N}$-methylthiourea, N-ethylthiourea, and their antimony(III) compounds in dimethyl sulfoxide is described in Figures 3 and 4. Free thioureas and their antimony(III) halide compounds exhibit one major absorption band in the UV region. Compounds 1-4 exhibit at $257.50 \mathrm{~nm}$ (1), $258.00 \mathrm{~nm}$ (2), $257.50 \mathrm{~nm}$ (3) and 258.50 (4), respectively, 
which are assigned to the $n-n^{*}$ transitions. The corresponding absorption band at the free ligands is found at $256.50 \mathrm{~nm}$ (NMTU and NETU). The absorption bands shift to lower energy from chloro to bromo $\mathrm{Sb}$ (III) compounds.

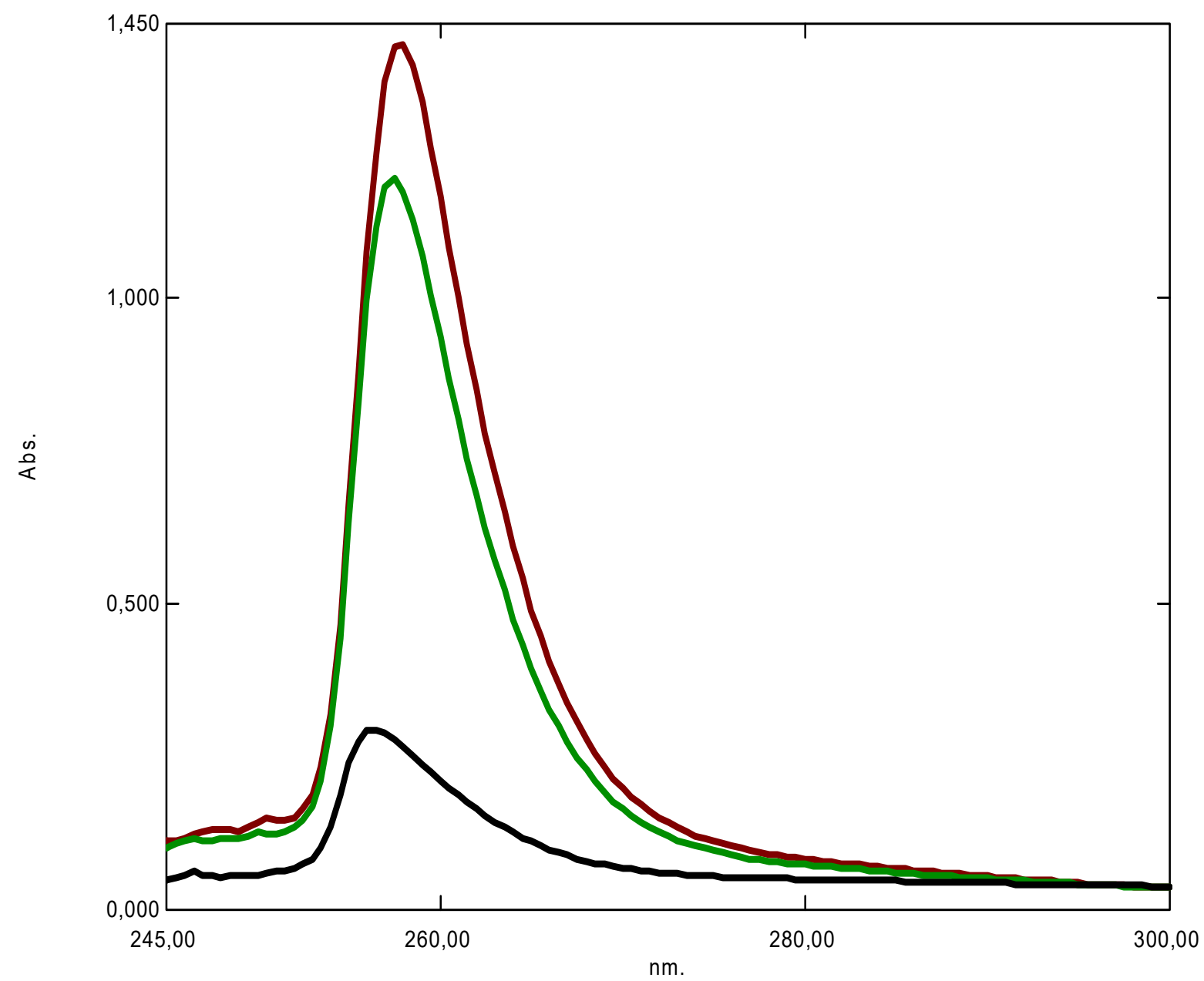

Figure 4.Uv-Vis absorption spectra of N-methylthiourea $(-),\left[\mathrm{SbCl}_{3}(\mathrm{NMTU})_{3}\right](\mathbf{1})(-)$ and $\left[\mathrm{SbBr}_{3}(\mathrm{NMTU})_{3}\right](\mathbf{2})(-)$ 
(A)

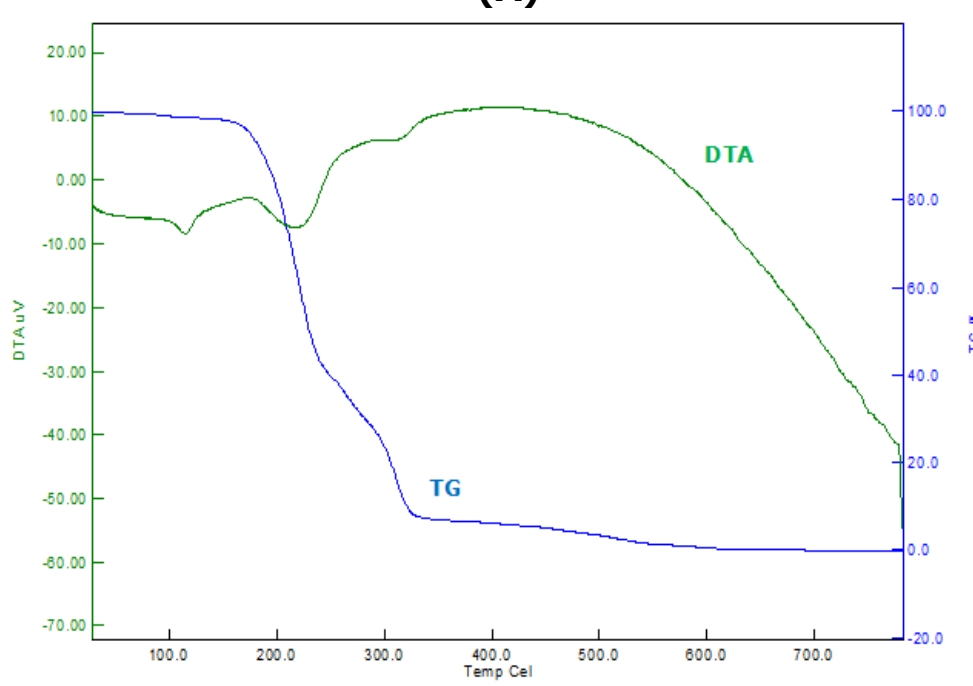

(C)

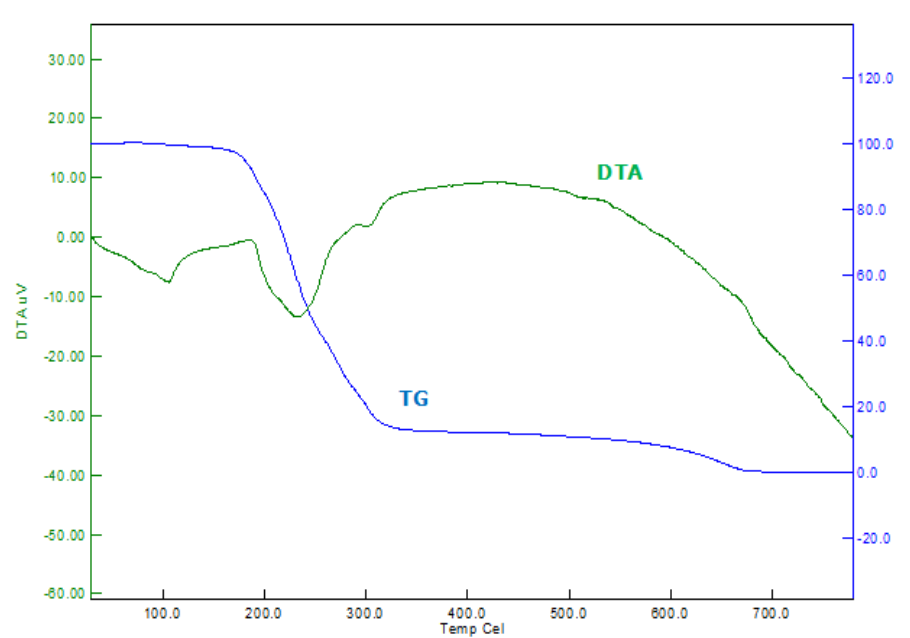

(B)

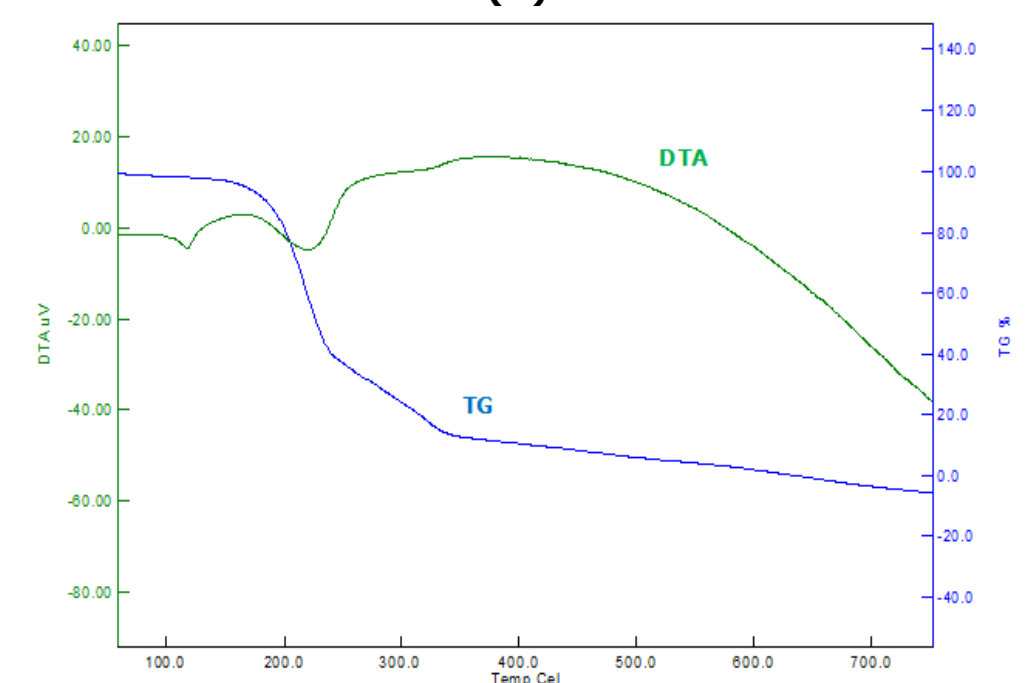

(D)

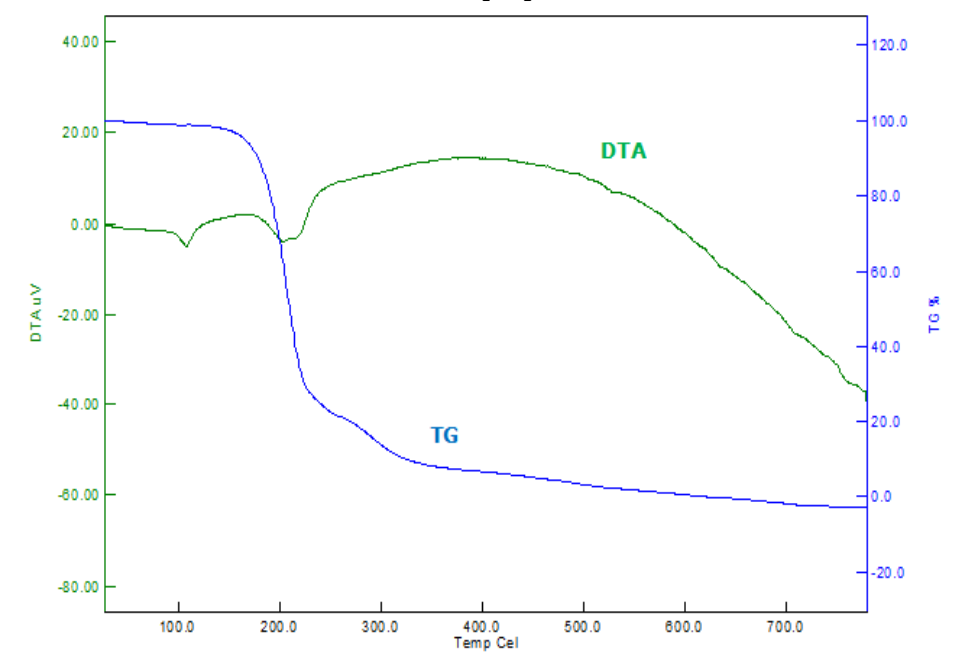

Figure 3. TG and DTA curves for compounds $(\mathrm{A})\left[\mathrm{SbCl}_{3}(\mathrm{NMTU})_{3}\right](\mathbf{1}),(\mathrm{B})\left[\mathrm{SbBr}_{3}(\mathrm{NMTU})_{3}\right](\mathbf{2}),(\mathrm{C})\left[\mathrm{SbCl}_{3}\left(\mathrm{NETU}_{3}\right](\mathbf{3})\right.$ and $(\mathrm{D})\left[\mathrm{SbBr}_{3}(\mathrm{NETU})_{3}\right]$ (4) 


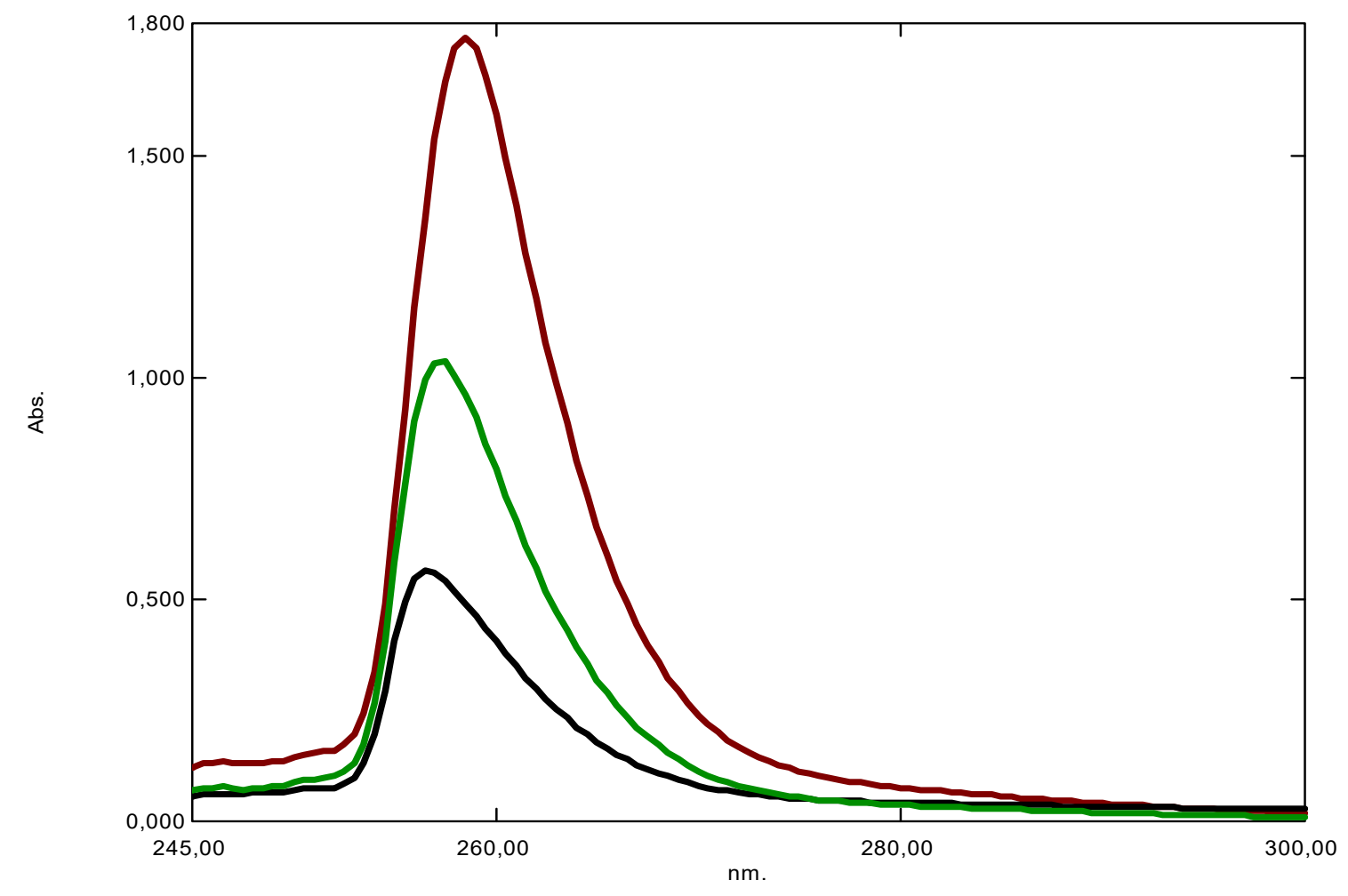

Figure 5. UV-Vis absorption spectra of $\mathrm{N}$-ethylthiourea (-), $\left[\mathrm{SbCl}_{3}(\mathrm{NETU})_{3}\right](\mathbf{3})(-)$ and

$$
\left[\mathrm{SbBr}_{3}(\mathrm{NETU})_{3}\right](\mathbf{4})(-) \text {. }
$$

\section{NMR Spectral Studies}

The ${ }^{1} \mathrm{H}$ and ${ }^{13} \mathrm{C}$ NMR chemical shifts of $\mathrm{N}$-methylthiourea, $\mathrm{N}$-ethylthiourea and those of the antimony(III) halide compounds 1-4 in DMSO- $d_{6}$ are summarized in Table 3 (Figures S5-S14). In the ${ }^{1} \mathrm{H}$ NMR spectra of the compounds, the $\mathrm{N}-\mathrm{H}$ signal of thiourea ligands became less intense upon coordination and shifted downfield from their positions in the free ligands. The deshielding is related to an increase in $\mathrm{n}$-electron density in the $\mathrm{C}-\mathrm{N}$ bond upon coordination $[27,29,30$, 34]. The appearance of the $\mathrm{N}-\mathrm{H}$ signal shows that the $\mathrm{N}$-methylthiourea and $\mathrm{N}$-ethylthiourea are coordinated to antimony(III) via the thione group. Table 3 shows that the $\mathrm{N}-\mathrm{H}$ protons of NMTU and NETU are nonequivalent ( $\mathrm{NH}_{2}$ appears as a doublet) and also after coordination $\mathrm{N}-\mathrm{H}$ protons of compounds 1-4 are nonequivalent. It should be noted that NMTU and NETU in ${ }^{13} \mathrm{C}$ NMR gives two signals for $>\mathrm{C}=\mathrm{S},-\mathrm{CH}_{2}-$ and $-\mathrm{CH}_{3}$ carbons for showing that the compounds exist in two isomeric forms [43]. The new signal observed at 3.49 (1), 3.60 (2), 3.49 (3) and 3.62 (4) ppm, respectively in the ${ }^{1} \mathrm{H}$ NMR spectra. These new signals are attributed to the halogen-hydrogen interaction. All other resonance signals of the thioureas remain un-shifted in the spectra of the compounds. However, such narrow shifts were also monitored for antimony(III) halide compounds with thione ligands [17-20]. 
Table 3. Chemical shifts (ppm) of the resonance signals observed in ${ }^{1} \mathrm{H}$ and ${ }^{13} \mathrm{C}$ NMR spectra of free thioureas and their antimony(III) compounds 1-4 in DMSO- $d^{6}$.

\begin{tabular}{|c|c|c|}
\hline Compounds & $\begin{array}{c}{ }^{1} \text { H NMR chemical shifts } \\
\text { (ppm) }\end{array}$ & $\begin{array}{c}{ }^{13} \mathrm{C} \text { NMR chemical shifts } \\
\text { (ppm) }\end{array}$ \\
\hline N-methylthiourea (NMTU) & $\begin{array}{c}7.64,7.47,6.93(\mathrm{~N}-\mathrm{H}) \\
2.84,2.64\left(-\mathrm{CH}_{3}\right)\end{array}$ & $\begin{array}{c}184.94,181.87(>\mathrm{C}=\mathrm{S}) \\
31.97,30.80\left(-\mathrm{CH}_{3}\right)\end{array}$ \\
\hline$\left[\mathrm{SbCl}_{3}(\mathrm{NMTU})_{3}\right](\mathbf{1})$ & $\begin{array}{c}7.68,7.50,6.98(\mathrm{~N}-\mathrm{H}) \\
2.84,2.64\left(-\mathrm{CH}_{3}\right) \\
3.49(\mathrm{Cl} \cdots \mathrm{H})\end{array}$ & $\begin{array}{c}184.95,181.83(>\mathrm{C}=\mathrm{S}) \\
31.92,30.76\left(-\mathrm{CH}_{3}\right)\end{array}$ \\
\hline$\left[\mathrm{SbBr}_{3}\left(\mathrm{NMTU}_{3}\right](\mathbf{2})\right.$ & $\begin{array}{c}7.73,7.51,7.16(\mathrm{~N}-\mathrm{H}) \\
2.84,2.65\left(-\mathrm{CH}_{3}\right) \\
3.60\left(\mathrm{Br}^{-\cdots} \mathrm{H}\right)\end{array}$ & $\begin{array}{c}184.91,181.26(>\mathrm{C}=\mathrm{S}) \\
31.96,30.84\left(-\mathrm{CH}_{3}\right)\end{array}$ \\
\hline N-ethylthiourea (NETU) & $\begin{array}{c}7.53,7.23,6.88(\mathrm{~N}-\mathrm{H}) \\
3.41,3.07\left(-\mathrm{CH}_{2^{-}}\right) \\
1.05-1.08, \mathrm{t}\left(-\mathrm{CH}_{3}\right)\end{array}$ & $\begin{array}{c}183.83,180.95(>\mathrm{C}=\mathrm{S}) \\
39.66,38.60\left(-\mathrm{CH}_{2}-\right) \\
15.45,14.88\left(-\mathrm{CH}_{3}\right)\end{array}$ \\
\hline$\left[\mathrm{SbCl}_{3}(\mathrm{NETU})_{3}\right](\mathbf{3})$ & $\begin{array}{c}7.68,7.55,6.90(\mathrm{~N}-\mathrm{H}) \\
3.38,3.06\left(-\mathrm{CH}_{2^{-}}\right) \\
1.05-1.08, \mathrm{t}\left(-\mathrm{CH}_{3}\right) \\
3.49(\mathrm{Cl} \cdots \mathrm{H}) \\
\end{array}$ & $\begin{array}{c}183,83180.79(>\mathrm{C}=\mathrm{S}) \\
39.66,38.59\left(-\mathrm{CH}_{2}^{-}\right) \\
15.48,14.85\left(-\mathrm{CH}_{3}\right)\end{array}$ \\
\hline$\left[\mathrm{SbBr}_{3}(\mathrm{NETU})_{3}\right](4)$ & $\begin{array}{c}7.73,7.56,6.90(\mathrm{~N}-\mathrm{H}) \\
3.38,3.07\left(-\mathrm{CH}_{2^{-}}\right) \\
1.05-1.08, \mathrm{t}\left(-\mathrm{CH}_{3}\right) \\
3.62(\mathrm{Br} \cdots \mathrm{H})\end{array}$ & $\begin{array}{c}183.80,180.37(>\mathrm{C}=\mathrm{S}) \\
38.63,38.63\left(-\mathrm{CH}_{2}^{-}\right) \\
15.45,14.83\left(-\mathrm{CH}_{3}\right)\end{array}$ \\
\hline
\end{tabular}

Kinetic study of the peroxidation of linoleic acid by lipoxygenase in the presence of antimony(III) compounds 1-4 and free thioureas

Because lipoxygenase inhibition is found to induce apoptosis [25] the effect of compounds 1-4 and free ligands on the oxidation of linoleic acid by lipoxygenase were studied in a vast concentration area. The degree of lipoxygenase activity $(A, \%)$ in the presence of these compounds was calculated according to the process described previously [38]. Figures 6 and 7 compares the inhibitory effect of 1-4 in different concentrations. The IC 50 values which were found for antimony(III) compounds are $44.22 \mu \mathrm{M}$ (1), $39.63 \mu \mathrm{M}$ (2),45.05 $\mu \mathrm{M}$ (3) and $53.55 \mu \mathrm{M}$ (4), N-methylthiourea (NMTU) $221.66 \mu \mathrm{M}$ and for N-ethylthiourea (NETU) $217.65 \mu \mathrm{M}$, respectively. Thus, all four compounds show higher inhibitory activity of lipoxygenase than free thioureas (N-methylthiourea (NMTU) and N-ethylthiourea (NETU)) and moreover, antimony(III) halide compounds of N-methylthiourea (1 and $\mathbf{2}$ ) show higher inhibitory activity of lipoxygenase than antimony(III) halide compounds of $\mathrm{N}$-ethylthiourea ( $\mathbf{3}$ and $\mathbf{4}$ ). 


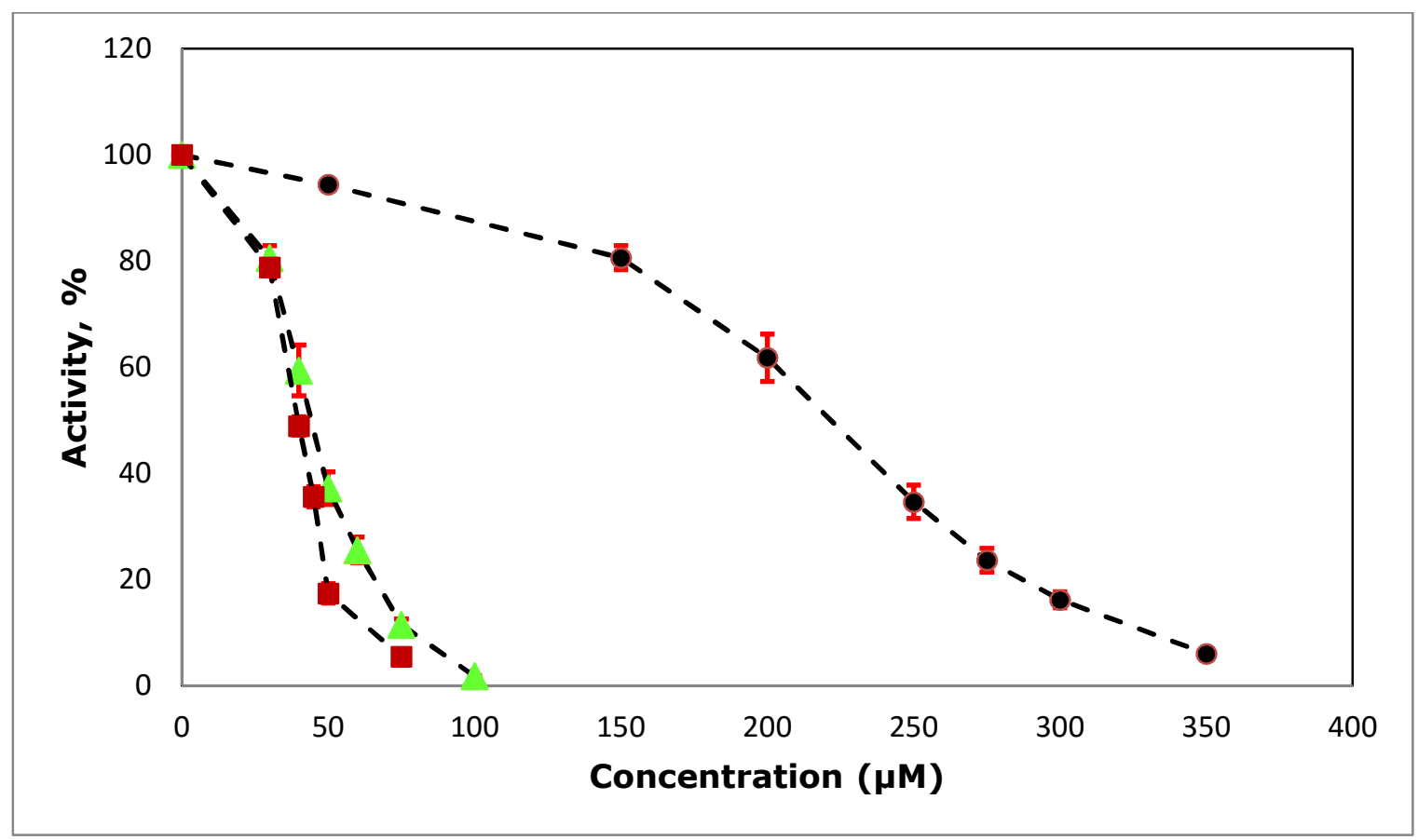

Figure 6. The inhibitory effect against lipoxygenase caused by $(\Delta)\left[\mathrm{SbCl}_{3}(\mathrm{NMTU})_{3}\right]$ (1), $(\boldsymbol{\square})\left[\mathrm{SbBr}_{3}(\mathrm{NMTU})_{3}\right](\mathbf{2})$, and $(\bullet) \mathrm{N}$-methythiourea in various concentrations.

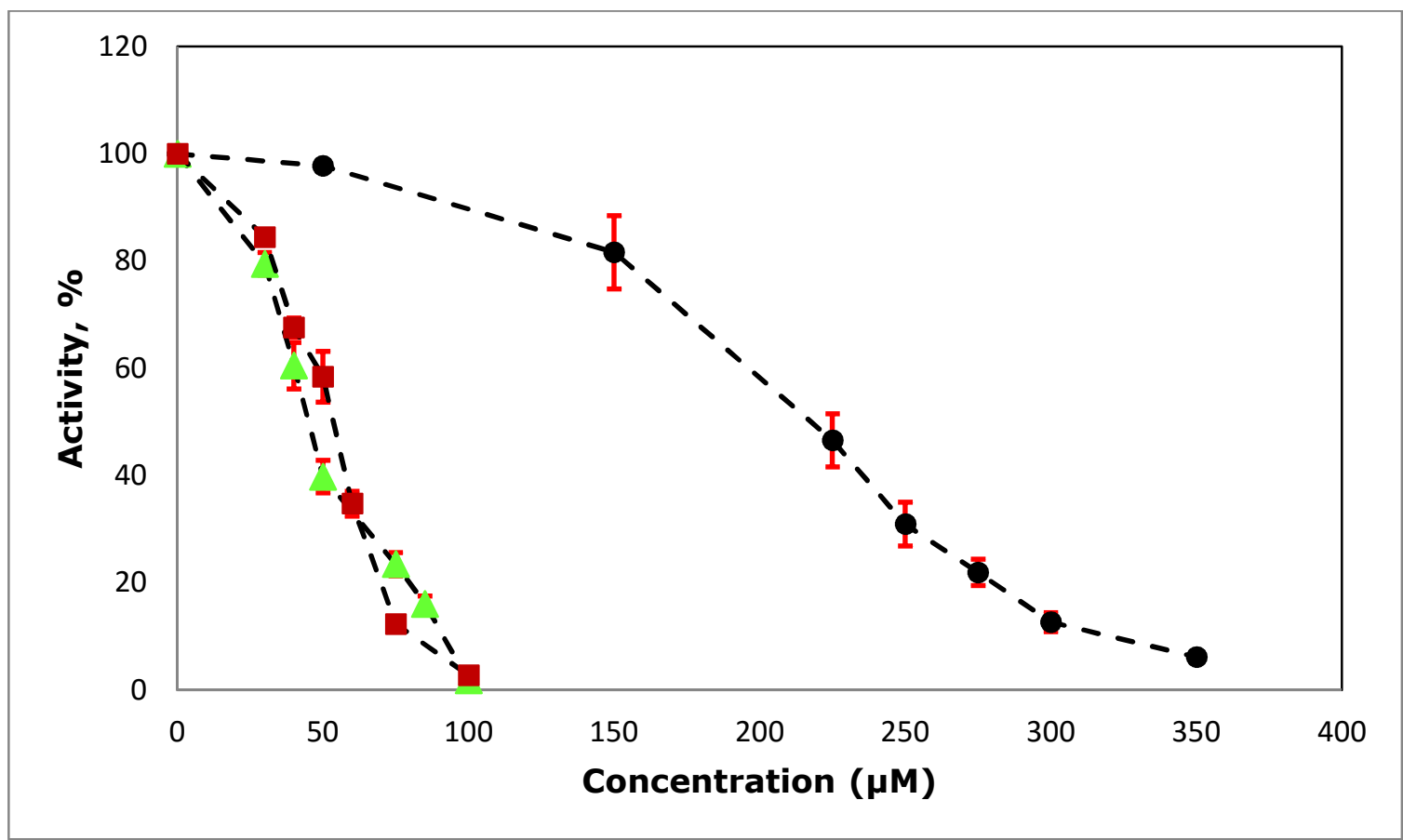

Figure 7. The inhibitory effect against lipoxygenase caused by $(\triangle)\left[\mathrm{SbCl}_{3}(\mathrm{NETU})_{3}\right]$ (3), $(\boldsymbol{\square})\left[\mathrm{SbBr}_{3}(\mathrm{NETU})_{3}\right](\mathbf{4})$, and $(\bullet)$ N-ethythiourea in various concentrations. 


\section{CONCLUSIONS}

$\mathrm{N}$-alkyl thioureas, namely $\mathrm{N}$-methylthiourea (NMTU) and $\mathrm{N}$-ethylthiourea (NETU) react with antimony(III) halides (halide: $\mathrm{Cl}$ or $\mathrm{Br}$ ) to form compounds of formulas [ $\left.\mathrm{SbCl}_{3}(\mathrm{NMTU})_{3}\right]$ (1), $\left[\mathrm{SbBr}_{3}(\mathrm{NMTU})_{3}\right]$ (2), $\left[\mathrm{SbCl}_{3}(\mathrm{NETU})_{3}\right]$ (3) and $\left[\mathrm{SbBr}_{3}(\mathrm{NETU})_{3}\right]$ (4). The reactions of $\mathrm{N}$ methylthiourea (NMTU) and N-ethylthiourea (NETU) with $\mathrm{SbX}_{3}\left(\mathrm{X}=\mathrm{Cl}\right.$ or $\mathrm{Br}$ ) in a 2:1 $\mathrm{HL} / \mathrm{SbX}_{3}$ rate, but unexpected compounds were formed in a $3: 1 \mathrm{HL} / \mathrm{SbX}_{3}$ rate. All antimony(III) halide compounds are neutral with octahedral $\left(\mathrm{O}_{h}\right)$ geometry. All four compounds show higher inhibitory activity of lipoxygenase than free thioureas ( $\mathrm{N}$-methylthiourea (NMTU) and $\mathrm{N}$ ethylthiourea (NETU)) and moreover, antimony(III) compounds of N-methylthiourea (1-2) show higher inhibitory activity of lipoxygenase than antimony(III) compounds of N-ethylthiourea (34). On the other hand, while antimony(III) halide compounds 1-4 display similar lipoxygenase inhibition with other antimony (III) compounds, they display lower lipoxygenase inhibition than the tin compounds in the literature $[14,38]$.

\section{ACKNOWLEDGEMENTS}

This work has been supported by Namik Kemal University (Project No. NKUBAP.01.GA.16.014).

\section{REFERENCES}

1. Norman NC, Editor. Chemistry of Arsenic, Antimony and Bismuth. Blackie Academic and Professional; 1998. ISBN: 978-0-7514-0389-3.

2. Sun H, Editor. Biological Chemistry of Arsenic, Antimony and Bismuth. Wiley. 2010. ISBN: 978-0-47071390-7.

3. Parrilha GL, Dias RP, Rocha WR, Mendes IC, Benítez D, Varela J, Cerecetto H, M. González M, Melo CML, Neves JKAL, Pereira VRA, Beraldo H. 2-Acetylpyridine and 2-benzoylpyridine-derived thiosemicarbazones and their antimony(III) complexes exhibit high anti-trypanosomal activity. Polyhedron, 2012; 31; 614-21.DOI:10.1016/j.poly.2011.10.018.

4. Ajaz H, Hussain S, Altaf M, Stoeckli-Evans $H$, Isab AA, Mahmood R, Altaf S, Ahmad S. Synthesis and Characterization of Antimony(III) Complexes of Thioamides, and Crystal Structure of $\left\{[\mathrm{Sb} \text { (Imt })_{2} \mathrm{Cl}_{2}\right]_{2}((2-\mathrm{Imt})\} \mathrm{Cl}_{2}$ (Imt=Imidazolidine-2-thione). Chinese Journal of Chemistry, 2011; 29; 254-58. DOI: $10.1002 /$ cjoc. 201190074.

5. Barnes NA, Godfrey SM, Pritchard RG, Ratcliffe S. The reactions of $\mathrm{SbX}_{3}(X=\mathrm{Cl}, \mathrm{Br}, \mathrm{I}) \mathrm{with} \mathrm{N}-$ methylbenzothiazole-2-thione (mbtt) and $\mathrm{N}$-methylbenzothiazole-2-selone (mbts). Formation of the mixed mer/fac-complex [mer-SbBr $(\text { mbts })_{2}$ ( $\mu$-mbts)fac- $\mathrm{SbBr}_{3}$ (mbts) $)_{2} \cdot \mathrm{CH}_{2} \mathrm{Cl}_{2}$. Polyhedron, 2010; 29; 1822-32. DOI:10.1016/j.poly.2010.02.029.

6. Bukvetskii BV, Sedakova TV, Mirochnik AG. Crystal structure and luminescence of antimony(III) bromide with aniline. Journal of Structural Chemistry. 2009; 50; 322-27. DOI:10.1007/s10947009-0044-9.

7. Barnes NA, Godfrey SM, Pritchard RG, Ratcliffe S. The reaction of N,N '-Di-tert-butylthiourea (dtbtu) with antimony(III) halides-formation of the triply bridged [(dtbtu)SbX2(mu-X)(2)(mu- 
dtbtu)SbX2(dtbtu)] ( $X=\mathrm{Cl}, \mathrm{Br}$ ) dimers. European Journal of Inorganic Chemistry.2008; 3661-67. DOI: $10.1002 /$ ejic. 200800252 .

8. Yin HD, Zhai J, Sun YY, Wang DQ. Synthesis, characterizations and crystal structures of new antimony (III) complexes with dithiocarbamate ligands. Polyhedron. 2008; 27; 663-70. DOI: $10.1016 /$ j.poly.2007.10.019.

9. Hadjikakou SK, Ozturk II, Banti CN, Kourkoumelis N, Hadjiliadis N. Recent advances on antimony(III/V) compounds with potential activity against tumor cells. Journal of Inorganic Biochemistry. 2015; 153; 293-305. DOI: 10.1016/j.jinorgbio.2015.06.006.

10. Hadjikakou SK, Antoniadis CD, Hadjiliadis N, Kubicki M, Binolis J, Karkabounas S, Charalabopoulos K. (2005) Synthesis and characterization of new water stable antimony(III) complex with pyrimidine2-thione and in vitro biological study. Inorganica Chimica Acta. 2005; 358; 2861-66. DOI: $10.1016 /$ j.ica.2004.06.028.

11. Ozturk II, Hadjikakou SK, Hadjiliadis N, Kourkoumelis N, Kubicki M, Baril M, Butler IS, Balzarini J. Synthesis, structural characterization, and biological studies of new antimony(III) complexes with thiones. The influence of the solvent on the geometry of the complexes. Inorganic Chemistry. 2007; 46; 8652-61. DOI: $10.1021 /$ ic700756e.

12. Ozturk II, Hadjikakou SK, Hadjiliadis N, Kourkoumelis N, Kubicki M, Tasiopoulos AJ, Scleiman H, Barsan MM, Butler IS, Balzarini J. New antimony(III) bromide complexes with thioamides: synthesis, characterization, and cytostatic properties. Inorganic Chemistry. 2009; 48; 2233-45. DOI: $10.1021 /$ ic8019205.

13. Hadjikakou SK, Ozturk II, Xanthopoulou MN, Zachariadis PC, Zartilas S, Karkabounas S and Hadjiliadis N. Synthesis, structural characterization and biological study of new organotin(IV), silver(I) and antimony(III) complexes with thioamides. Journal of Inorganic Biochemistry. $2008 ; 102 ; 1007-15$. DOI: $10.1016 /$ j.jinorgbio.2007.12.027.

14. Ozturk I, Filimonova S, Hadjikakou SK, Kourkoumelis N, Dokorou V, Manos MJ, Tasiopoulos AJ, Barsan MM, Butler IS, Milaeva ER, Balzarini J, Hadjiliadis N. Structural motifs and biological studies of new antimony(III) iodide complexes with thiones. Inorganic Chemistry. 2010; 49; 488-501. DOI: 10.1021/ic901442e.

15. Ozturk II, Metsios AK, Filimonova-Orlova S, Kourkoumelis N, Hadjikakou SK, Manos E, Tasiopoulos AJ, Karkabounas S, Milaeva ER and Hadjiliadis N. Study on single crystal structure of the antimony(III) bromide complex with 3-methyl-2-mercaptobenzothiazole and biological activity of some antimony(III) bromide complexes with thioamides. Medicinal Chemistry Research. 2012; 21; 352331. DOI 10.1007/s00044-011-9905-9.

16. Ozturk II, Kourkoumelis N, Hadjikakou SK, Manos MJ, Tasiopoulos AJ, Butler IS, Balzarini J and Hadjiliadis N. Interaction of antimony(III) chloride with thiourea, 2-mercapto-5-methylbenzimidazole, 3-methyl-2-mercaptobenzothiazole, 2-mercaptopyrimidine, and 2mercaptopyridine. Journal of Coordination Chemistry. 2011; 64; 3859-71. DOI: 10.1080/00958972.2011.633603.

17. Ozturk II, Banti CN, Manos MJ, Tasiopoulos AJ, Kourkoumelis N, Charalabopoulos K and Hadjikakou SK. Synthesis, characterization and biological studies of new antimony(III) halide complexes with $\omega$-thiocaprolactam. Journal of Inorganic Biochemistry. 2012; 109; 57-65. DOI: 10.1016/j.jinorgbio.2012.01.014.

18. Ozturk II, Urgut OS, Banti CN, Kourkoumelis N, Owczarzak AM, Kubicki M, Charalabopoulos K and Hadjikakou SK. Synthesis, structural characterization and cytotoxicity of the antimony(III) chloride complex with N,N-dicyclohexyldithiooxamide Polyhedron. 2013; 52; 1403-10. DOI: $10.1016 /$ j.poly.2012.04.038

19. Ozturk II, Urgut OS, Banti CN, Kourkoumelis N, Owczarzak AM, Kubicki M and Hadjikakou SK. Synthesis, structural characterization and cytostatic properties of $\mathrm{N}, \mathrm{N}$-dicyclohexyldithiooxamide complexes of antimony(III) halides (SbX3, X: $\mathrm{Br}$ or I). Polyhedron. 2014; 70; 172-79. DOI: 10.1016/j.poly.2013.12.025. 
20. Han A, Ozturk II, Banti CN, Kourkoumelis N, Manoli M, Tasiopoulos AJ, Owczarzak AM, Kubicki M and Hadjikakou SK. Antimony(III) halide compounds of thioureas: Structures and biological activity. Polyhedron. 2014; 79; 151-60. DOI: 10.1016/j.poly.2014.05.014.

21. Urgut OS, Ozturk II, Banti CN, Kourkoumelis N, Manoli M, Tasiopoulos AJ and Hadjikakou SK. New antimony(III) halide complexes with dithiocarbamate ligands derived from thiuram degradation: The effect of the molecule's close contacts on in vitro cytotoxic activity. Materials Science and Engineering C. 2016; 58; 396-408. DOI: 10.1016/j.msec.2015.08.030.

22. Urgut OS, Ozturk II, Banti CN, Kourkoumelis N, Manoli M, Tasiopoulos AJ and Hadjikakou SK. Addition of tetraethylthiuram disulfide to antimony(III) iodide; synthesis, characterization and biological activity.InorganicaChimicaActa. 2016; 443; 141-150. DOI: 10.1016/j.ica.2015.12.028.

23. Samuelsson B, Dahlen SE, Lindgren J, Rouzer CA, Serhan CN. Leukotrienes and lipoxins: structures, biosynthesis, and biological effects. Science. 1987; 237; 1171-76. DOI: 10.1126/science.2820055

24. Knapp MJ, Klinman JP. Kinetic Studies of Oxygen Reactivity in Soybean Lipoxygenase-1. Biochemistry. 2003; 42; 11466-75. DOI: 10.1021/bi0300884.

25. Ding $X Z$, Kuszynski CA, El-Metwally TH, Adrian TE. Lipoxygenase Inhibition Induced Apoptosis, Morphological Changes, and Carbonic Anhydrase Expression in Human Pancreatic Cancer Cells. Biochemical and Biophysical Research Communications. 1999; 266; 392-99. DOI: 10.1006/bbrc.1999.1824.

26. Pidgeon GP, Lysaght J, Krishnamoorthy S, Reynolds JV, O’Byrne K, Nie D, Honn KV. Lipoxygenase metabolism: roles in tumor progression and survival. Cancer Metastasis Reviews. 2007; 26; 26 (2007) 503-24. DOI: 10.1007/s10555-007-9098-3.

27. Bourne S, Koch KR. Intramolecular hydrogen-bond controlled unidentate co-ordination of potentially chelating $\mathrm{N}$-acyl-N'-alkylthioureas: crystal structure of cis-bis(N-benzoyl-N'-propylthiourea) dichloroplatinum(II). Journal of the Chemical Society, Dalton Transactions. 1993; 13; 2071-72. DOI: $10.1039 / D T 9930002071$.

28. Kucukguzel I, Kucukguzel SG, Rollas S, Kiras M. Some 3-Thioxo/alkylthio-1,2,4-triazoles with a substituted thiourea moiety as possible antimycobacterials. Bioorganic Medicinal Chemistry Letters. 2001; 11; 1703-07. DOI: 10.1016/S0960-894X(01)00283-9.

29. Venkatachalam TK, Sudbeck EA, Uckun FM. Regiospecific synthesis, X-ray crystal structure and biological activities of 5-bromothiophenethyl thioureas. Tetrahedron Letters. 2001; 42; 6629-32. DOI: $10.1016 /$ S0040-4039(01)01290-4.

30. Campo RD, Criado JJ, Gheorghe R, Gonzalez FJ, Hermosa MR, Sanz F, Manzano JL, Monte E, RodrıguezFernandez E. N-benzoyl-N'-alkylthioureas and their complexes with $\mathrm{Ni}$ (II), $\mathrm{Co}$ (III) and Pt(II) crystal structure of 3-benzoyl-1-butyl-1-methyl-thiourea: activity against fungi and yeast. Journal of Inorganic Biochemistry. 2004; 98; 1307-14. DOI: 10.1016/j.jinorgbio.2004.03.019.

31. Ahmad S, Isab AA, Ahmad S. ${ }^{1} \mathrm{H},{ }^{13} \mathrm{C},{ }^{15} \mathrm{~N}$ NMR and IR Spectroscopic Studies of a Rh(II) Complex of Thiourea. Journal of Coordination Chemistry. 2003; 56; 1587-95.DOI: 10.1080/00958970310001641688.

32. Rodríguez-Fernández E, Manzano JL, Benito JJ, Hermosa R, Monte E, Criado JJ. Thiourea, triazole and thiadiazine compounds and their metal complexes as antifungal agents. Journal of Inorganic Biochemistry. 2005; 99; 1558-72. DOI: 10.1016/j.jinorgbio.2005.05.004.

33. Plutín AM, Alvarez A, Mocelo R, Ramos R, Castellano EE, da Silva MM, Colina-Vegas L, Pavan FR, Batista AA. Anti-Mycobacterium tuberculosis activity of platinum(II)/N,N-disubstituted-N'-acyl thiourea complexes. Inorganic Chemistry Communications. 2016; 63; 74-80. DOI: 10.1016/j.inoche.2015.11.020.

34. Schwade VD, Kirsten L, Hagenbach A, Lang ES, Abram U. Indium(III), lead(II), gold(I) and copper(II) complexes with isophthaloylbis(thiourea) ligands. Polyhedron. 2013; 55; 155-61. DOI: $10.1016 /$ j.poly.2013.03.008. 
35. Bowmaker GA, Pakawatchai C, Saithong S, Skelton BW, White AH, Structural and spectroscopic studies of some adducts of silver(I) halides withthiourea and N-ethyl substituted thioureas. Dalton Transactions. 2010; 39; 4391-4404. DOI: 10.1039/C001398F.

36. Hough E, Nicholson DG. Stereochemical role of lone pairs in main-group elements. Part 2. Structure and bonding in trichloro(tetramethylthiourea)antimony(III) studied by means of X-ray crystallography and antimony-121 Mössbauer spectroscopy. Journal of the Chemical Society, Dalton Transactions. $1981 ; 10 ; 2083-87$. DOI: $10.1039 /$ DT9810002083.

37. Xanthopoulou MN, Hadjikakou SK, Hadjiliadis N, Milaeva ER, Gracheva YA, Tyurin VY, Kourkoumelis N, Christoforidis KC, Metsios AK, Karkabounas S, and Charalabopoulos K. Biological studies of new organotin(IV) complexes of thioamide ligands. European Journal of Medicinal Chemistry. 2008; 43; 327-35. DOI: 10.1016/j.ejmech.2007.03.028.

38. Xanthopoulou MN, Hadjikakou SK, Hadjiliadis N, Kubicki M, Karkabounas S, Charalabopoulos K, Kourkoumelis N, and Bakas T. Synthesis and characterization of a new chloro-di-phenyltin(IV) complex with 2-mercapto-nicotinic acid: Study of its influence upon the catalytic oxidation of linoleic acid to hydroperoxylinoleic acid by the enzyme lipoxygenase. Journal of Organometallic Chemistry. 2006; 691; 1780-89. DOI: 10.1016/j.jorganchem.2005.11.073.

39. Glick D, Editor. Methods of Biochemical Analysis, Volume 2. Interscience Publishers. 1955. ISBN: 9780471304593.

40. Lopez-Nicolas JM, Bru R, Sanchez-Ferrer A, Carcia-Carmona A. An Octaethylene Glycol Monododecyl Ether-Based Mixed Micellar Assay for Lipoxygenase Acting at Neutral pH. Analytical Biochemistry. $1994 ; 221$; 410-15. DOI: 10.1006/abio.1994.1435.

41. Axelrod B, Cheesbrough TM, Laakso S. [53] Lipoxygenase from soybeans: EC 1.13.11.12 Linoleate: oxygen oxidoreductase. Methods Enzymology. 1981; 71; 441-451. DOI:10.1016/0076$6879(81) 71055-3$.

42. Refat MS, Killa HMA, Fetooh H. Spectroscopic and thermal characterization of $\mathrm{Cu}(\mathrm{II}), \mathrm{Co}(\mathrm{II}), \mathrm{Ni}(\mathrm{II})$ and $\mathrm{Mn}(\mathrm{II})$ complexes of fluorescent dye 4-N,N-dimethyl-ethanolamine-N-allyl-1,8-naphthalimide (4DMEAN). Journal of Molecular Structure. 2010; 983; 122-132. DOI: $10.1016 /$ j.molstruc. 2010.08.041.

43. Nadeem S, Rauf MK, Ahmad S, Ebihara M, Tirmizi SA, Bashir SA, Badshah A. Synthesis and characterization of palladium(II) complexes of thioureas. X-ray structures of [Pd(N, $N^{\prime}-$ dimethylthiourea) $\left.)_{4}\right] \mathrm{Cl}_{2} .2 \mathrm{H}_{2} \mathrm{O}$ and $[\mathrm{Pd} \text { (tetramethylthiourea) })_{4} \mathrm{Cl}_{2}$. Transition Metal Chemistry. 2009; 34; 197-202. DOI: 10.1007/s11243-008-9177-5. 
Türkçe Öz ve Anahtar Kelimeler

\title{
Bazı n-Alkil Tiyoüreler İçeren Yeni Antimon(III) Halojenür Kompleksleri: Sentez, Karakterizasyon ve Linoleik Asidin Hidroperoksilinoleik Aside Lipoksijenaz ile Katalitik Yükseltgenmesindeki Etkilerinin İncelenmesi
}

\author{
Ibrahim Ismet Ozturk
}

\begin{abstract}
Öz: Dört yeni tiyoüre-antimon(III) bileşiği $\left(\mathrm{SbX}_{3} ; \mathrm{X}=\mathrm{Cl}\right.$ veya $\mathrm{Br}$ ) sentezlenmiştir. Kullanılan üre türevleri N-metiltiyoüre (NMTU) ve N-etiltiyoüre (NETU) olup oluşan komplekslerin kapalı formülleri $\left.\left[\mathrm{SbCl}_{3}(\mathrm{NMTU})_{3}\right](\mathbf{1}), \mathrm{SbBr}_{3}(\mathrm{NMTU})_{3}\right](\mathbf{2}),\left[\mathrm{SbCl}_{3}(\mathrm{NETU})_{3}\right]$ (3) ve $\left[\mathrm{SbBr}_{3}(\mathrm{NETU})_{3}\right]$ (4) olarak belirlenmiştir. Bu yeni antimon(III) halojenürler erime noktası, elementel analiz, molar iletkenlik, FT-Kızılötesi spektroskopisi, FT-Raman spektroskopisi, UV-Vis spektrofotometrisi NMR $\left({ }^{1} \mathrm{H}\right.$ ve $\left.{ }^{13} \mathrm{C}\right)$ spektroskopisi ve TG-DTA analizi ile karakterize edilmiştir. N-Metiltiyoüre (NMTU) ve $\mathrm{N}$-etiltiyoüre (NETU) ile $\mathrm{SbX}_{3}(\mathrm{X}=\mathrm{Cl}$ veya $\mathrm{Br})$ arasındaki 2:1 ligand/metal oranındaki tepkimeden 3:1 ligand metal oranına sahip beklenmeyen ürünler elde edilmiştir. Bileşikler çözeltide nonelektrolit olarak bulunur ve bileşiklerin spektroskopik verileri altı koordinasyonlu oktahedral geometri ile uyumludur, bu komplekslerde üç halojenür iyonu ve üç tiyoüre kükürt atomu bulunmaktadır. N-Metiltiyoüre ve N-etiltiyoüre ligandları 1-4 bileşiklerinde kükürt üzerinden bağlanan monodentat bir karaktere sahiptir. 1-4 bileşiklerinin, N-metiltiyoüre ve $\mathrm{N}$ etiltiyoürenin, linoleik asidin hidroperoksilinoleik aside lipoksijenaz ile katalitik peroksidasyonu ile dönüşmesi kinetik olarak çalışılmıştır.
\end{abstract}

Anahtar kelimeler: Antimon(III) halojenürler; N-alkil tiyoüreler; spektroskopik karakterizasyon; lipoksijenaz.

Sunulma: 23 Temmuz 2016. Kabul: 01 Ekim 2016. 